\title{
Geo-school project: Educational technologies to teach geoscience
}

\author{
Vinícius Arcanjo Monteiro \\ Teaching and History of Earth Science, University of Campinas, São Paulo, Brazil.
}

How to cite this paper: Vinícius Arcanjo Monteiro(2020). Geo-school project: Educa- tional technologies to teach geoscience. The Educational Review, USA, 4(3), 45-53.

DOI: $10.26855 /$ er.2020.03.001

Received: May 2, 2019

Accepted: June 27, 2019

Published: March 9, 2020

Corresponding author: Vinícius Arcanjo Monteiro, Teaching and History of Earth Science, University of Campinas, São Paulo, Brazil.

Email:viniciusmonteiro@ige.unicamp.br

\begin{abstract}
The Geo-School project offers digital didactic materials to teachers of Brazilian basic education of a given region. The material in a website comprises geologic data, images and maps. The idea and purpose of the project is to shape a design of teaching materials using educational technologies. The first step is identify the themes that should be emphazised in classroom. After the themes are prioritized the resulting interaction involves lectures, theoretical-practical courses and fieldwork. Although the Geo-School project has already been developed for others regional realities, the proposed research intends to introduce the study module of the Poços de Caldas Alkaline Massif - Brazil. The region has numerous works of reference on geology, provided by scientific production, but the use of this material does not go (unfortunately) beyond the academic-university circuit. Education should allow any individual to recognize what this massif is, how it functions and the way life relationships develop, both in time and space. In a broad sense, Geosciences may help students to construct an idea on mechanisms of earth evolution and on the permanent interaction between the Earth spheres. The use of computers in education may explore visual language, which is strongly connected to geologic reasoning, as well as some typical methodological procedures of Geology, multiple explanatory hypotheses, scientific descriptions, historical and analogical reasoning. This requires more incentive towards teacher training programs. Many specialists of the national community of Geology are the most capable people to decode main concepts from a great volume of available information. Promoting interaction with teachers for diffusion of Geosciences.
\end{abstract}

\section{Keywords}

Educational Technologies; Teaching Geoscience; Poços de Caldas (Brazil)

\section{Introduction}

Information technologies have played important roles in our everyday practices, and education could not be different: an observation of this scenario shows that technologies have infiltrated the educational-pedagogical practices of geosciences in schools. Proof of this is Portugal, for example, that the "GEOPOR" program was created, the Earth 2 Class project in the United States, the Earth Learning Idea in UK and the Geo-School in Brazil. These are projects created and developed online. They aim to provide educational methodologies for learning about the Earth System. Thus, by means of contributions important works carried out by geoscientists such as José Brilha, Michael Passow, 
Chris King, Celso dal Ré Carneiro and Ronaldo Barbosa, admit the teaching of online geosciences as a new paradigm and that, although new, have been tested with promising results.

In the case of Brazil, the Geo-School Project aims to provide geological data, images and maps of a given region, in a format of didactic material with computer support, to elementary and middle school teachers. The Project is an initiative of planning educational actions geological knowledge directed to the use of Information and Communication Technologies - as a didactic tool. According to the authors of the Geo-School proposal, the preliminary results of the consultation of 168 schools (...) suggest that the project may result in geoscience teaching initiatives adapted to other regional realities (Carneiro \& Barbosa, 2005).

For some generations, science has looked at the gaps / spaces to answer a question that is at the heart of this process: can technology revolutionize education? In studying this process Barbosa (2013) observes that in Brazil neither the school as well as the teachers were prepared - when the initial step of inserting the computers in the school had been given. It was all very new for both teachers and students and more, whether computer science was a discipline or a multidisciplinary use? The fact is that it started a race in schools to adapt the laboratories for the use of computer, proof of this is the National Program of Educational Technology - PROINFO1. And that teachers and students still did not have access to computers at home which made it harder to use and learn.

According to Moura (2007, p. 5), "teachers feel powerless, incapable of working with students using computers" [...], causing the use and effective incorporation of the equipment as a didactic tool to be abandoned. As the author says, very often "aware of the importance of computer science in the school and the need to incorporate it into their professional practice, teachers [...] feel they lack a course that enables them to work using computers. (Luiz et al, 2013. p 157)

Throughout history the attempt to understand if there was a "gain" in schools with the use of computers has always been the subject of constant discussions among scientists. However, because of the complexity that accompanies these issues, the answer remains in the dim light of uncertainties and incongruities.

\section{History of Geo-School Project In Brazil}

The Project began in 2002 with a pilot plan based on the following assumptions: i. The lack of a specific discipline in Brazilian basic education that shelters the contents of geosciences; ii. the knowledge of geosciences is confined to sparse insertions in the disciplines of geography and science; iii. the occurrence of a predominance of lectures, possibly illustrated by the teacher; iv. It is not recognized the degree of use, nor the validity of the use of the computer as a didactic tool for the teaching of the geosciences. (Piranha, 2006). Thus, the Geo-School Project http://v.rwvv.geo-escola.pro.br was developed to "provide geological data, images and maps, of a given region, in a format of didactic material with computer support, to teachers of primary and secondary education "(Carneiro \& Barbosa 2005, p.71).

The theoretical framework of Carneiro \& Barbosa (2002a, 2002b, 2003) was used to develop the pilot module (Barbosa 2003) developed for the region of Atibaia, Cajamar, Campo Limpo Paulista, Franco da Rocha, Francisco Morato, Judiai, Jarinu, Mairiporã and Várzea Paulista. The research tool was a survey conducted with teachers of science and geography of primary and secondary education in these municipalities. In the survey the teachers indicated the topics that they considered as more relevant for the teaching of geosciences at these levels. From these themes, didactic

1 It is an educational program with the purpose of promoting the pedagogical use of information technology in the public basic education network. The program takes computers, digital resources and educational content to schools. In contrast, states, Federal District and municipalities should ensure the adequate structure to receive laboratories and prepare educators to use the machines and technologies. 
material, in CD-ROM format, with slide-show sequences, an editor capable of generating new sequences and a small database of images and photographs, the particular aspects presented there, to facilitate the use of these materials by the teacher, when elaborating his classes. (PIRANHA, 2006)

In 2006, the São José do Rio Preto module of the Geo-School Project was carried out with the same objectives, but with a more focused approach to the culture of sustainability. The São José do Rio Preto module of the Geo-School Project sought to investigate what knowledge of geosciences, and to what extent, are important for the construction of an innovative culture [...]. In this, the proposal of fomenting the use of local geological information and fieldwork as teaching tools (Piranha, 2006) was added to the basic objectives of the Geo-School.

\section{Goal}

Obtain and take geoscientific data to communities beyond the university academic circuit and use the educational technologies as a vehicle to deploy this use in schools.

\section{Methodology}

We chose to start this work with a historiographic survey of the Geo-School Project. Analyzing, in this context, continuities and ruptures of the scientific process besides demonstrating the propulsion of the project in progress. We observed that the years 2002, 2003, 2005 and 2006 are theoretical milestones of the Geo-School project.

Allied to this theoretical material were consulted some works about projects that use information technology and communication in proposals of the geoscientific matter, but as it is a subject that does not have many works of reference becomes important the study on the subject.

A questionnaire was applied to 21 geography teachers from the Poços de Caldas municipal education network, in order to outline teaching strategies in context with local concerns and needs. The questionnaire covered the following topics:

a) 15 main (general) themes on teaching geosciences:

1. Relief, topography, spatial location, maps;

2. Minerals and rock classification;

3. Universe and Earth formation;

4. Geological history of the planet;

5. Geological scale;

6. Nature cycles;

7. Water, rivers and hydrological cycle;

8. Earth spheres, tectonic plates, volcanoes, earthquakes;

9. Humidity, energy and climate;

10. Weathering and soils, types of soil, soil movements;

11. Risks of natural accidents and urban occupation;

12. Geology and geological evolution of the Poços de Caldas region

13. Geological Heritage of the Alkaline Massif of Poços de Caldas;

14. Rocks and Minerals Catalog (Resk Frayha Collection - Poços de Caldas Historical and Geographic Museum)

15. Fieldwork in the Poços de Caldas region.

b) 9 specific themes of the geology of Poços de Caldas: geochronology; geotectonic interpretation; mineralogy and petrography; zircon and "caldasito"2; uranium and molybdenum; thorium, rare earth and iron; hydrothermal alteration;

${ }^{2}$ Regional name used 
bauxite and weathering; hydrogeology.

c) the frequency of teachers on the use of the school's computer lab

d) which technological device was used among the options: TV, Datashow, PC, Notebook, smartphone and tablet.

e) the teachers' cognitive perception regarding the use of technology in the classroom. (level of abstraction / attention)

f) use of geotechnology in deed.

Finally, a conclusive analysis will be carried out on the importance of educational technologies in Geography teaching, under geological heritage approach, that is, the systematization of strategic ideas related to geoconservation and applicability in teaching.

\section{Geo-School: Module Poços de Caldas - Minas Gerais State}

\subsection{Introduction}

The Poços de Caldas module has the same basic objectives of the Geo-School Project. It aims to provide geological data of the region, in addition to the academic-university circuit, using information and communication technologies as a 'driving force' and their use in the teaching of geosciences. It presents as a differential the thesis that, geological matters geared to the geological heritage of the region (Monteiro, 2018) can be managed as educational through didactic-pedagogical treatments.

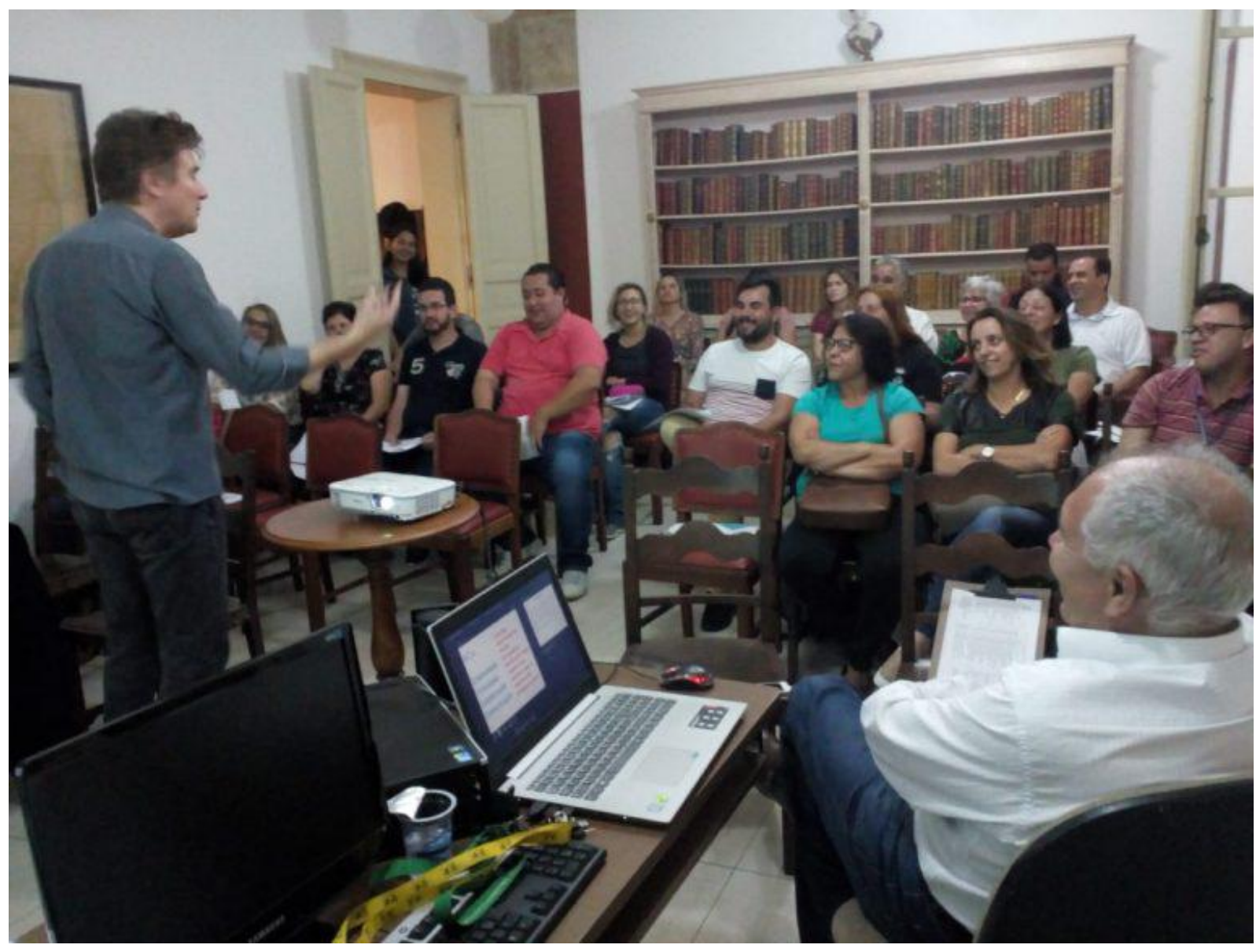

Figure 1: Geo-School Meeting. Archive 2019 


\subsection{Map of the schools pre-selected}

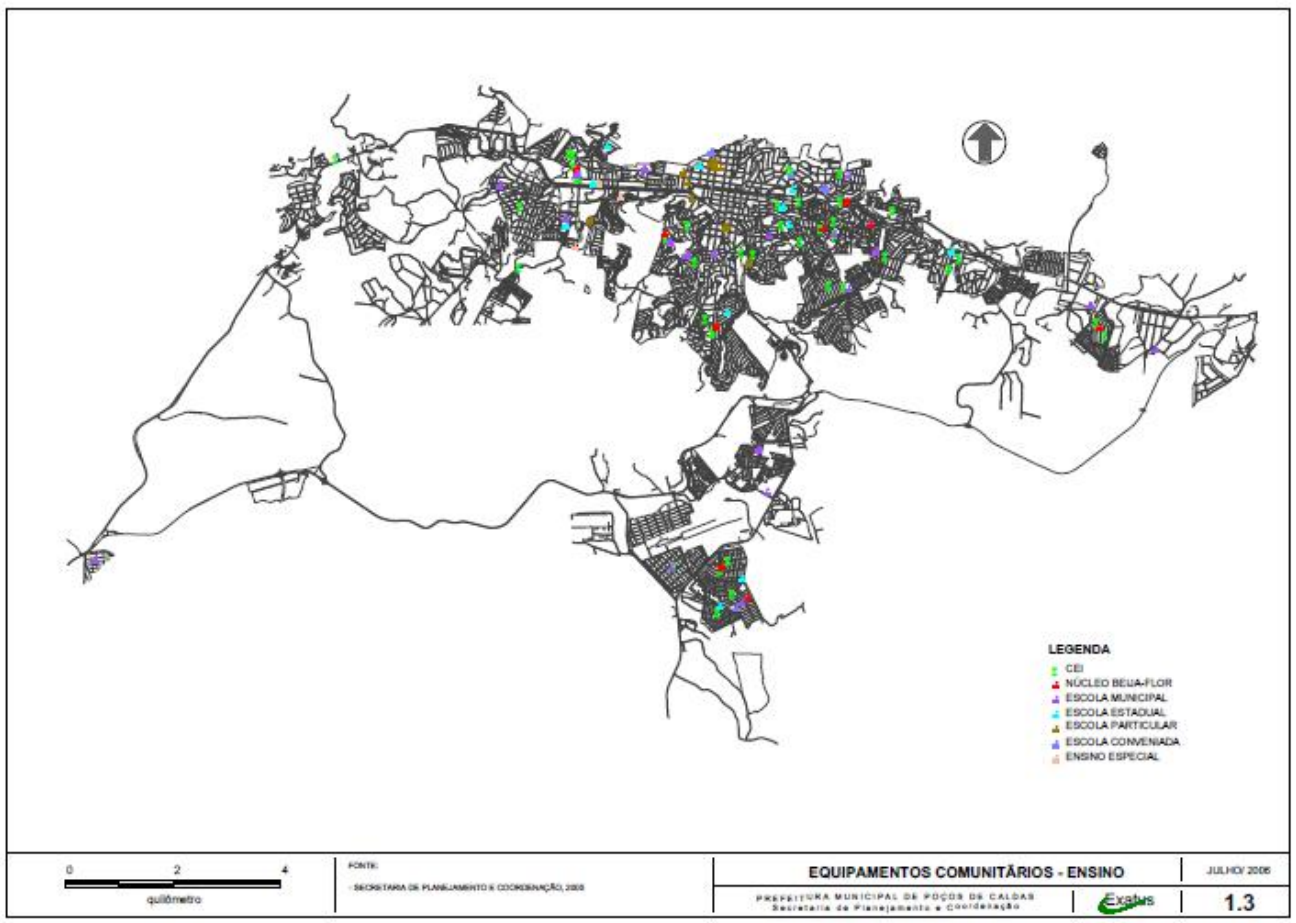

Figure 2: Thematic Map of Poços de Caldas: Schools. From Management Plan of the City, 1996.

\subsection{Results}

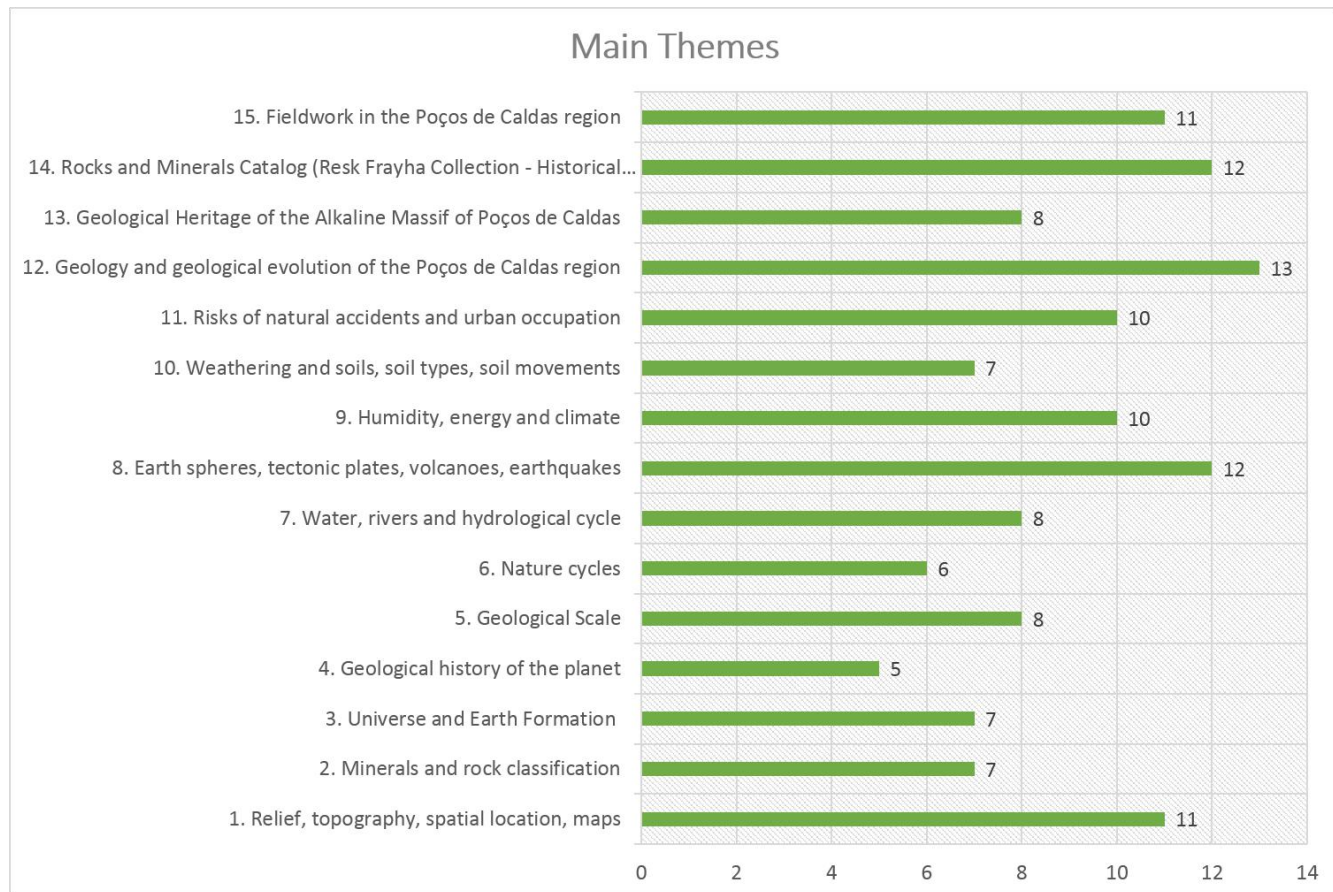

Figure 3: Graphical result analysis: main themes (sample universe: 21 teachers) 


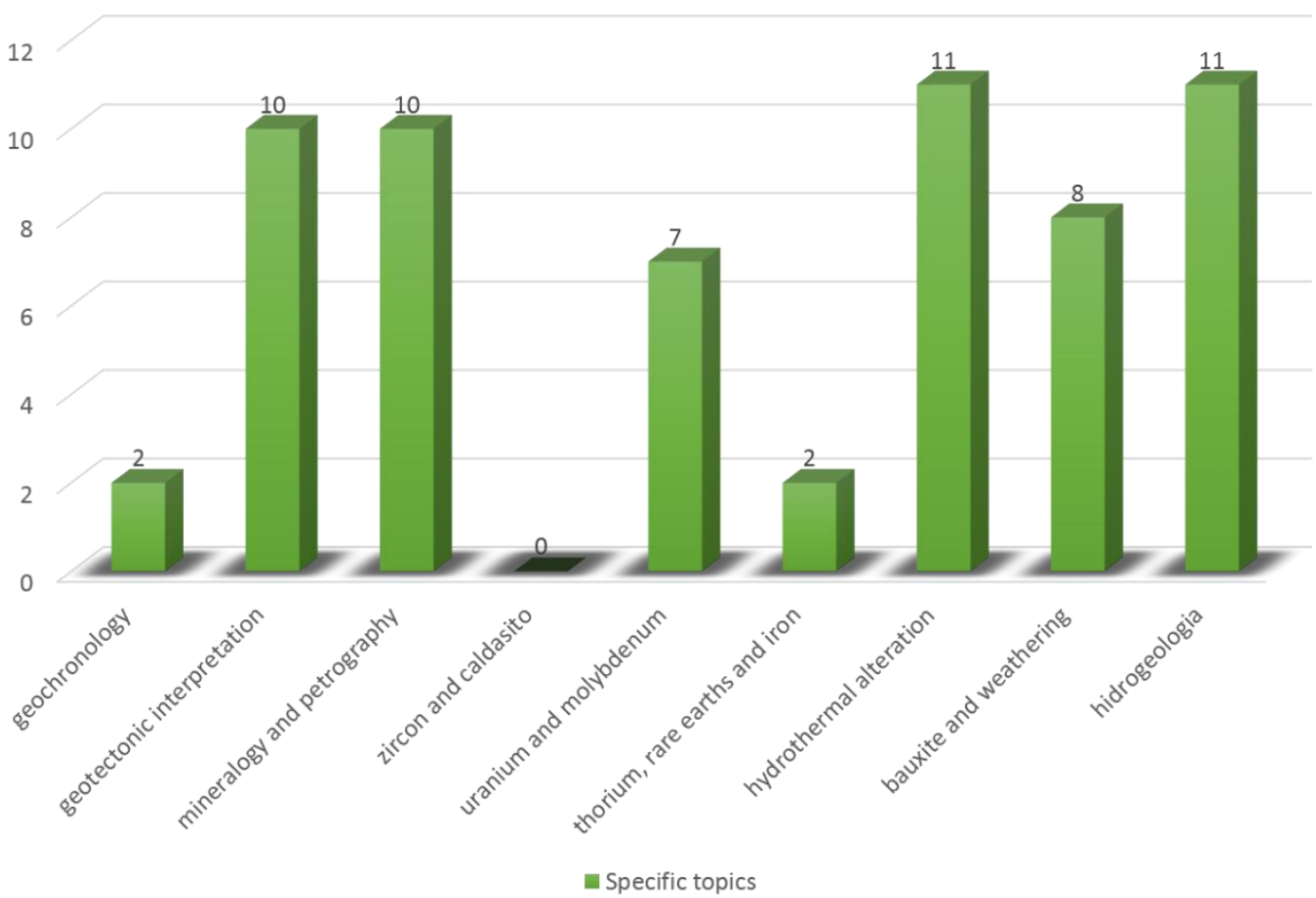

Figure 4: Graphical result analysis: specific topics (sample universe: 21 teachers)

12

8

6

4

$\underline{+}$

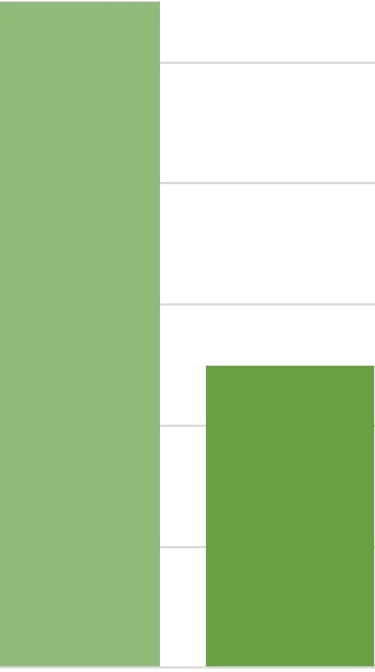

use of the computer lab

\begin{tabular}{|l|l|}
\hline$\square$ The school does not have a computer lab & \\
\hline $\mathbf{1}$ to 3 times a month & \\
\hline $\mathbf{\square}$ At least once a week & \\
\hline $\mathbf{\square}$ Every class & \\
\hline
\end{tabular}

Figure 5: Graphical result analysis: frequency of use of the computer lab (sample universe: 21 teachers) 


\section{USE OF TECHNOLOGICAL DEVICE}

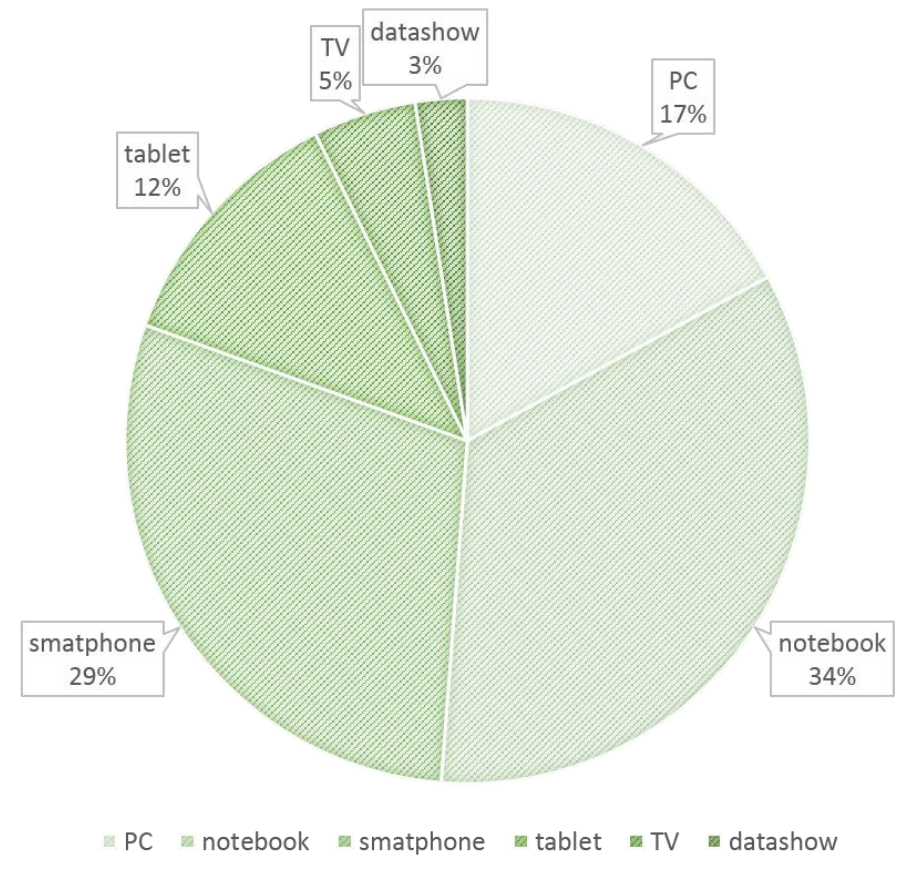

Figure 6: Graphical result analysis: use of technological device (sample universe: 21 teachers)

\section{COGNITIVE PERCEPTION (USE OF TECHNOLOGY IN THE CLASSROOM)}

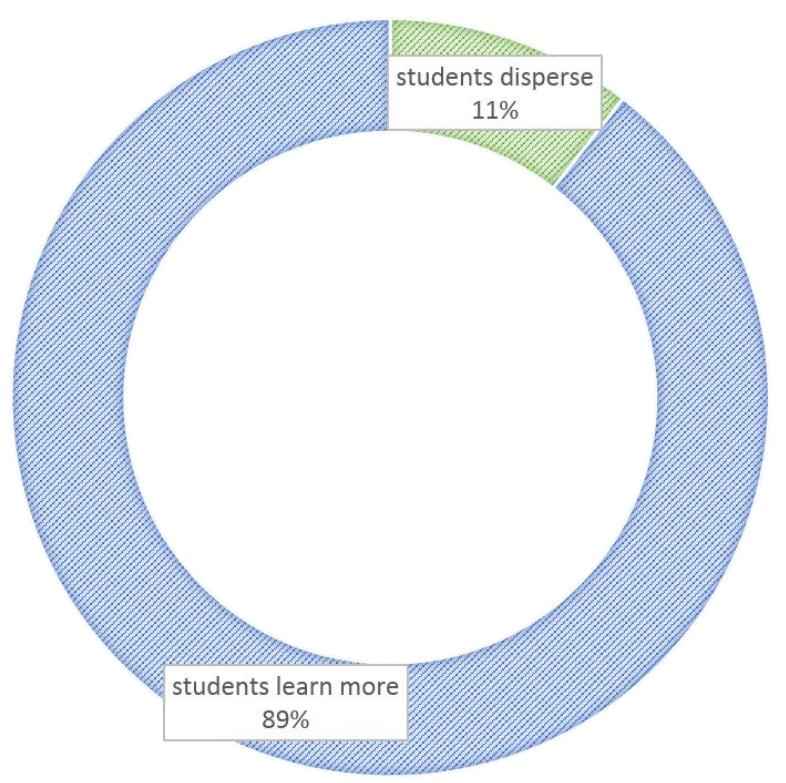

students disperse

students learn more

Figure 7: Graphical result analysis: cognitive perception (sample universe: 21 teachers) 


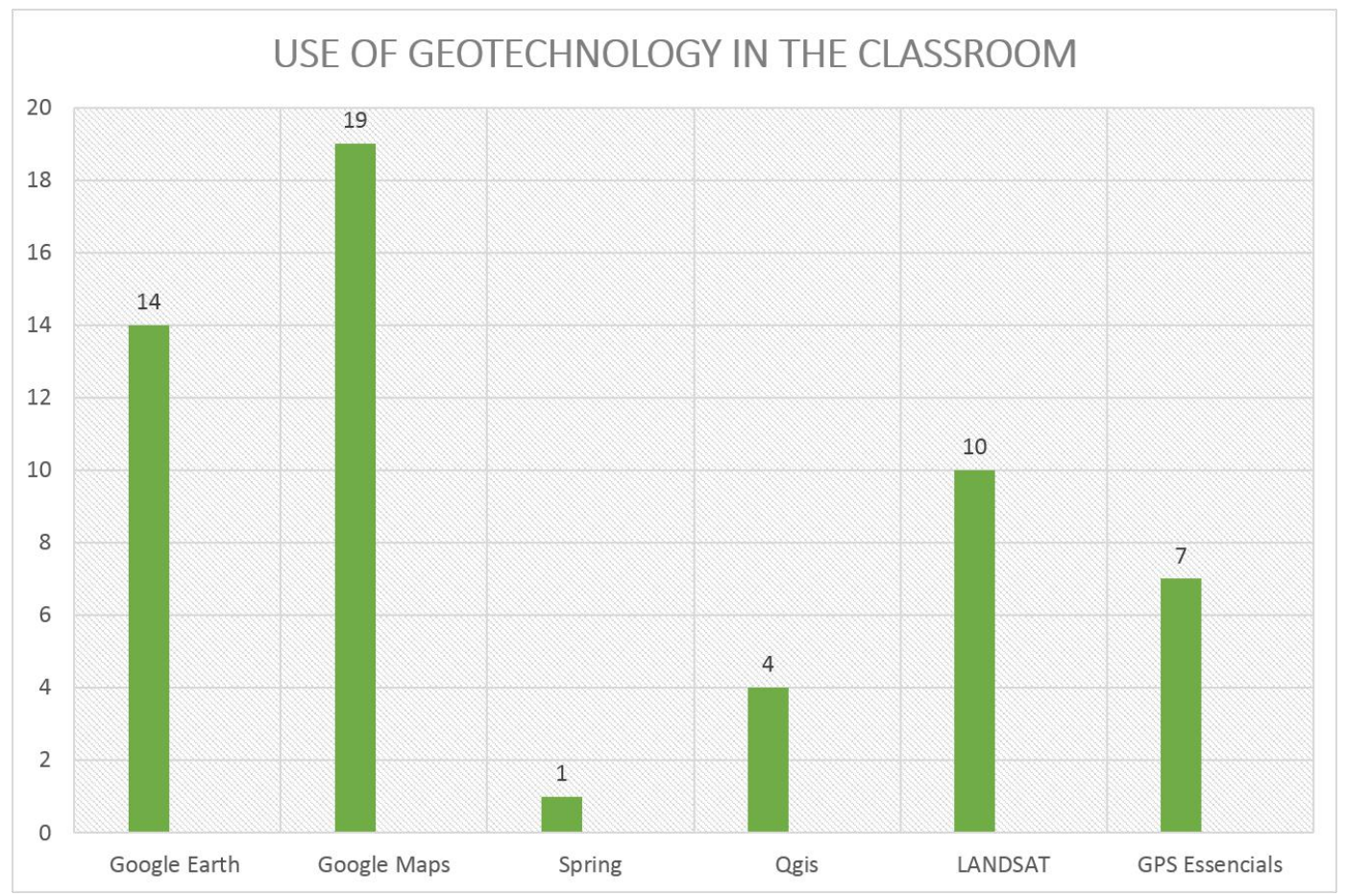

Figure 8: Graphical result analysis: use of geotechnology (sample universe: 21 teachers)

We consider the graphs an inspiring answer for continuing the study. The main themes graph (Fig. 3) Shows us, in a strict sense, the importance of the graphic representation of the territory and the usefulness of cartographic instruments for understanding the space of Planet Earth. And, also, the need and priority of teachers to introduce students to the local scale.

The graphic: specific themes of the geology of Poços de Caldas (Fig. 4) Presents as a result not only the need to interpret the physical aspects of the region, but also the local economic and cultural aspects.

The graph: use of the computer lab (Fig. 5) Represents a moderate use of the computer lab. Which in turn (Fig. 6) Is represented by the use of notebook and datashow, used mainly in expository classes. The use of smartphones also represents a relevant didactic in use in the classroom.

$87 \%$ of teachers indicate the use of technology in the classroom (Fig. 7). The use of Google Earth is the most used platform (Fig. 8) among teachers.

\section{Final Considerations}

In the development of the research we seek to organize the demands of the schools, taking as an opportunity the reflection of the present challenges in the municipal scope. As expected in the initiation phases, in this work we did not stop to seek solutions to the problems arising from the insertion of computers in schools; but above all we orient ourselves to understand part of the problem in order to better deal with the challenges that follow in the research.

In this course we realize that the academic production presented for the Geo-School Project presents some characteristics previously presented, but worth reiterating in this point of the text:

- The absence in Brazilian basic education of a specific discipline that shelters the contents of geosciences;

- Knowledge of geosciences is limited to sparse insertions in the subjects of geography and science; 
- The occurrence of a predominance of lectures, possibly illustrated by the teacher;

- It is not recognized the degree of use, nor the validity of the use of the computer as a didactic tool for the teaching of geosciences.

Even considering that these characteristics are relevant to the understanding of our object of study, we call special attention to the latter insofar as the few possibilities that we had to advance in the construction of our current question; since it intends to understand, through the study of bibliographical production, the way in which the insertion of educational technologies in the teaching of geosciences has been dealt with.

The Geo-School Project: Poços de Caldas Module seeks to expand the possibilities of access to the knowledge of municipal educators, in order to provide constant improvement and professional appreciation. With continuous studies offered to the network, we aim to bring together the knowledge built between educators and students, academic research and basic education, favoring the sharing of knowledge historically produced by human work and, at the same time, helping to cope with current dilemmas.

Thus, we tend to believe that the Poços de Caldas Geo-School Module Project creates possibilities to advance our comprehension of our object of study with a future extension of the scope of the bibliographic base, being important, however, to emphasize that this first phase of the research seems to have signaled a gap in the production of knowledge regarding the question that we propose to answer through the bibliographic review. On the other hand, through this work, we also found that the use of educational technologies in school education of the municipal public network is still insipient, so the importance of studying the subject.

And when we return to thinking about the unfolding of geological heritage, it often comes with conclusions about the scientific production of this reality. Well, if public policies have not yet brought the expected results for the confirmation of this heritage, socio-educational actions can be better stimulated as the case of the Geo-School Project whose objective is the training and qualification of teachers and the learning need of this public.

\section{Acknowledgements}

The support of the Municipal Education Department of Poços de Caldas is being essential for the progress of the Geo-School Project: Poços de Caldas module. All teachers involved in. Also my lectures from University of Campinas: Celso dal Ré Carneiro and Ronaldo Barbosa \& colleagues Andrezza Azzi and Fernanda Ramos.

\section{References}

BARBOSA. R. (2013) Projeto Geo-escola: Geociências para uma escola inovadora. Tese de Doutorado. UNICAMP. Campinas - SP. $182 \mathrm{p}$.

CARNEIRO \& BARBOSA (2005). Projeto Geo-Escola: Disseminação de Conteúdos de Geociências por Meio do Computador para Docentes de Ciências e Geografia no Nível Fundamental em Jundiaí-Atibaia, SP. Geol. USP Publ. Espec., São Paulo, v. 3, p. 71-82, setembro.

KING C., Kennett P., Devon E (2018).Earthlearningidea: promoting deep questioning in lab and field. Terræ Didatica, 14(3):263-270. URL: http://www.ige.unicamp.br/terraedidatica/.

LUIZ B. R; MONTEIRO, V.A; SANTOS, G; XAVIER C. (2013). Desafios e potencialidades das TIC's frente ao fenômeno de juvenilização da EJA. In Educação e os processos de formação interdisciplinar: diálogos entre docência e pesquisa/ org. Fernanda Aparecida Ribeiro [et al] 1 ed. Curitiba. PR: CRV

MONTEIRO, V. A. \& BACCI, D. DE LA C. (2018) Recognition inventory of the Alkaline Massif of Poços de Caldas (MG). In: VIII Conference of the International Geoscience Education Organization and VIII National Symposium of Earth Sciences Teaching and History. Campinas - SP.

PIRANHA J. M. O ensino de geologia como instrumento formador de uma cultura de sustentabilidade: o projeto geo-escola em são josé do rio preto, sp. Tese de Doutorado. UNICAMP. Campinas - SP. 222 p.

POÇOS DE CALDAS. (1992) Plano Diretor. Prefeitura Municipal de Poços de Caldas - Secretaria de Planejamento e coordenação. 